\title{
Reproductive Traits of Sandbird Octopus, Amphioctopus aegina (Gray, 1849) from Mandapam Coastal Waters (Palk Bay), Southeast Coast of India
}

\author{
Boby Ignatius ${ }^{1}$, Muthukumarasamy Srinivasan ${ }^{2 *}$, and Srinivasan Balakrishnan ${ }^{2}$ \\ ${ }^{1}$ Central Marine Fisheries Research Institute, Cochin (CMFRI) P. O. Box 1603, Ernakulam North P.O. Cochin - 682 018, India \\ ${ }^{2}$ Centre of Advanced Study in Marine Biology, Faculty of Marine Sciences, Annamalai University, Parangipettai - 608502 Tamil \\ Nadu, India
}

Received 28 June 2011; Revised 14 July 2011; Accepted 16 August 2011

(c) KSO, KORDI and Springer 2011

\begin{abstract}
The sandbird octopus Amphioctopus aegina (Gray, 1849 ) is one of the important octopod species in trawl catches in Mandapam waters (Palk Bay). The reproductive biology of this species from these waters was studied from October 2001 to September 2002. In the majority of months(Jan-June), the sex ratio was biased towards males. The ratios of males to females increased consistently with respect to weight Total weight at first maturity were $78.78 \mathrm{~g}$ for females and $40.8 \mathrm{~g}$ for males. Four maturity stags were recognized for females and two for males. Maturation and spawning occur all year round, with a peak during October and another peak during JanuaryFebruary. In males, no definite seasonal changes were observed in gonadosomatic index (GSI) values. In females there were two peaks in GSI values during October and January-February. For individuals of a DML range of $67-85 \mathrm{~mm}$ fecundity varied between $2,962-8,820$ oocytes. The average relative fecundity was estimated at 68 to 83 and the average number oocytes per gram of ovary were 488 to 539 .
\end{abstract}

Key words - Amphioctopus aegina, maturation, spawning, fecundity, size at maturity

\section{Introduction}

Cephalopods started gaining importance in India with the development of export market and consequent increased in demand. Production of cephalopods from capture fisheries was estimated to be 12,8692 tons of which octopus constitute 4.39\%. Central Marine Fisheries Research Institute (CMFRI 2009). Amphioctopus aegina formed $70.7 \%$ of the total octopod catches of this Mandapam

\footnotetext{
*Corresponding author. E-mail: mahasrini1@gmail.com
}

coastal region (Ignatius 2005). Extensive reviews of cephalopod reproduction are available covering the main features of gamatogensis, maturation, mating and egg laying (Cortez et al. 1995; Gabr et al. 1998; Barratt et al. 2007; Stephen et al. 2008; Alves and Haimovici 2011).

Five reproductive strategies were described for cephalopods based on three features; ovulation pattern, spawning pattern, and whether or not growth occurs between spawning events. The five reproductive strategies defined were (a), spawning once, simultaneous terminal spawning, with synchronous ovulation, monocyclic spawning and absence of growth between egg batches. (b) Spawning more than once including: (i) polycyclic spawning with egg-laying occurring in separate batches during the spawning season and growth occurring between production of egg batches and spawning seasons; (ii) multiple spawning, with groupsynchronous ovulation, monocyclic spawning and growth between egg batches; (iii) intermittent terminal spawning, with group-synchronous ovulation, monocyclic spawning and no growth between egg batches; (iv) continuous spawning, with asynchronous ovulation, monocyclic spawning and growth between egg batches (Rocha et al. 2001). Most species of octopus species have simultaneous terminal spawning events that can occur year round or in one or two seasonal peaks. Males have year round maturation and a short life span of less than $<2$ years (Guerra 1975; Hatanaka 1979; Goncalves 1991; Sanchez and Obarti 1993; Semmens et al. 2004).

Although extensive studies exist regarding the reproductive biology of O. vulgaris (Smale and Buchan 1981; Whitakers 
et al. 1991; Silva et al. 2002; Hernanadez-Gracia et al. 2002; Smith and Grifiths 2002), few exist for other species. The present study was undertaken to describe the spawning season, size at first maturity, and fecundity of $A$. aegina. This forms a biological basis for the implementation of possible management measures aimed at sustainable exploitation of this resource. The current rate of exploitation is well below the maximum sustainable yield by operating more number of boats and nets in the study area. (Ignatius and Srinivasan 2006). The aim of this work is to study the reproductive biology of $A$. aegina in the subtropical environment of the continental shelf in Mandapam coastal region, which will allow for a better understanding of the reproductive strategy along the species distribution.

\section{Materials and Methods}

\section{Specimen collection}

Samples were collected from Palk Bay, in the Mandapam region (Lat. $79^{\circ} 10^{\prime} \mathrm{N}$; Long. $9^{\circ} 15^{\prime} \mathrm{E}$ ), on the southeast coast of India (Fig. 1). A total of 1,255 specimens (793 males and 462 females) of $A$. aegina were randomly collected over period of a year from October 2001 to September 2002 from commercial fishing trawlers. Because of the annual 45 days closed season for trawling on the southeast coast of

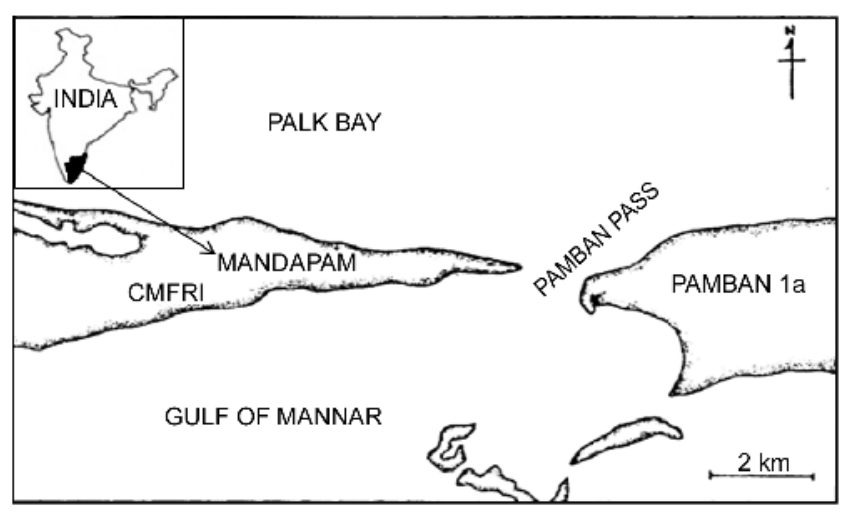

Fig. 1. Map showing the study area (Mandapam region, Palk Bay)
India during April 15 to May 30, May data were not available for analysis. The sex ratio of 631 specimens was determined by external examination, (392 males, 239 females), and these were preserved separately for further laboratory studies. They were thoroughly washed, weighed $(0.001 \mathrm{~g})$ and measured (dorsal mantle length, $\mathrm{mm})$. They were collected Octopus dissected and preserved in 10\% formaldehyde for later analysis. Gonads were removed and weighed.

\section{Data analysis}

\section{Sex ratio}

The sex ratio was calculated for each month and also for each $4-10 \mathrm{~cm}$. The homogeneity in the distribution of males and females was tested using the Chi-square test.

\section{Growth}

The length-weight relationships were calculated separately for females, males and then for population as a whole.

$$
G=\frac{\ln \left(W_{2}-\ln W_{1}\right)}{t_{2}-t_{1}} \times 100=\% \text { of body weight } / \text { day }
$$

Where,

$$
G \text { - growth; } W \text { - weight }
$$

\section{Maturity stages}

Maturity stages were determined by visual identification of characteristics in the preserved reproductive organs and derived from scales used by (Buckley 1976; Mangold 1987; Whitaker et al. 1991; Alvarez Perez and Haimovici 1991; Smith and Griffiths 2002; Smith et al. 2006). Each scale was expanded and modified for $A$. aegina accordingly. The female maturity stages were categorized as follows in this Table 1.

Males were classified as mature or immature based on the presence or absence of spermatophores in the Needham's sac.

Table 1. Female maturation stage in A. aegina

\begin{tabular}{cll}
\hline \hline Maturity stage & Morphological characters & \multicolumn{1}{c}{ Ova size } \\
\hline $\begin{array}{l}\text { Stage I, Immature } \\
\text { Stage II, Maturing }\end{array}$ & $\begin{array}{l}\text { Ovary small and white } \\
\text { Ovary granular with small ova, clearly visible medium-sized uniformly } \\
\text { whitish ova, but very few of them reticulated. }\end{array}$ & $<1 \mathrm{~mm}, 1-2 \mathrm{~mm}$ \\
Stage III, Mature & $\begin{array}{l}\text { ovary is large and occupies more than half of mantle cavity, loose oocytes } \\
\text { are present in the ovary }\end{array}$ & $<1 \mathrm{~mm}, 1-2 \mathrm{~mm}, 2-6 \mathrm{~mm}$ \\
Stage IV, Spent & ovary is flaccid with few loose Oocyte & $<1 \mathrm{~mm}, 1-2 \mathrm{~mm}, 2-6 \mathrm{~mm}, 6-15 \mathrm{~mm}$ \\
\hline
\end{tabular}




\section{Gonadosomatic index (GSI)}

For calculating the GSI, the weight of the reproductive organs (males: testis, Needhams sac and penis, and females: ovary and oviducal complex), and the total body weight of each animal were measured. The GSI was calculated using the following formula (Otero et al. 2007);

$$
\text { GSI } \%=\frac{\text { Weight of gonad }(\mathrm{g})}{\text { Total body weight }(\mathrm{g})} \times 100
$$

\section{Size at first maturity}

To estimate the mean lengths at 50\% maturity for males and females, a logistic function was fitted to the proportion of the mature individuals by size class using a non-linear regression of the following function:

$$
\mathrm{P}=1 /\{1+\exp [-\mathrm{a} / \mathrm{r}(\mathrm{L}-\mathrm{Lm})]\}
$$

(SPSS software was also used for the present work)

where $\mathrm{P}$ is the proportion of mature specimens in each size class, $r$ (- slope, $b$ ) is a parameter controlling the shape of the curve and $\mathrm{Lm}$ is the length at which $50 \%$ of specimen attains maturity. The $\mathrm{Lm}=\mathrm{a} / \mathrm{r}$ where ' $\mathrm{a}$ ' is the intercept.

\section{Fecundity}

Fecundity can be defined as the egg potential, or the number of eggs which are about to be released for fertilization, and which can develop into offspring. For estimating fecundity, the total weight of the ovaries was estimated and three samples were taken from each ovary. The number of eggs in each sample was counted after estimating the sample weight. The total number of eggs was calculated from the known weight of the samples and the full ovary as follows (Bensam 1999):

Total number of eggs in ovary $=$ (no. of eggs in the sample/weight of the sub sample) * weight of the ovary

The correlation coefficient (r) was calculated (Snedecor and Cochran 1967) to find out the relationship between fecundity and the mantle length, total body weight and ovary weight.

\section{Results}

\section{Sex ratio}

Out of 1,255 specimens examined (3.3 to $8.7 \mathrm{~cm}$ dorsal mantle length), there were 793 males and 462 females. The overall ratio of males to females was $1.71: 1.00$, which was significantly different from a 1:1 ratio $\left(\chi^{2}=87.9, P>0.05\right)$. The proportion of males was more in the samples collected and the details were given in the Table 1. There were significantly more males in all months except June and July, indicating a male biased population. Analysis of sex ratio based on mantle length revealed that the proportion of males to females increases as weight increases (Table 2).

\section{Growth}

The length-weight relationships were calculated separately for females, males and then for population as a whole. Based on the data and calculation the following lengthweight relationships were found: $\mathrm{W}=0.6697 \times \mathrm{DML}^{2.3516}$ $(\mathrm{r}=0.95)$ for males, $\mathrm{W}=0.6906 \times \mathrm{DML}^{2.4053}(\mathrm{r}=0.97)$ for females and $\mathrm{W}=0.6758 \times \mathrm{DML}^{2.3846}(\mathrm{r}=0.96)$ for all specimens analyzed. Analysis of covariance did not indicate significant differences in

Table 2. Monthly sex ratio of Amphioctopus aegina from October 2001 to September 2002 at Mandapam region of Palk Bay

\begin{tabular}{cccccc}
\hline \hline Months & No. of Octopus examined & Male & Female & Proportion of male & $\chi^{2}$ test \\
\hline Oct & 185 & 120 & 65 & 1.85 & $*$ \\
Nov & 149 & 98 & 51 & 1.92 & $*$ \\
Dec & 56 & 36 & 20 & 1.8 & $*$ \\
Jan & 43 & 30 & 13 & 2.31 & $*$ \\
Feb & 110 & 78 & 32 & 2.4 & $*$ \\
Mar & 68 & 48 & 20 & 1.63 & -- \\
Apr & 100 & 62 & 38 & 1.28 & \\
May & -- & -- & 1.34 & ns \\
Jun & 205 & 115 & 90 & 64 & ns \\
Jul & 150 & 86 & 64 & 1.75 & $*$ \\
Aug & 66 & 42 & 24 & 45 & $*$ \\
Sep & 123 & 78 & 45 & & $*$ \\
\hline
\end{tabular}

Significant $(\mathrm{P}<0.05)$ departs from 1:1 are indicated by *; ns - not significantly differ from 1:1 via chi square test 
Table 3. Sex ratio of different groups of Amphioctopus aegina based on dorsal mantle length from October 2001 to September 2002 at Mandapam region of Palk Bay

\begin{tabular}{|c|c|c|c|c|c|}
\hline Size groups (DML cm) & No. of Octopus examined & Male & Female & Proportion of male & $\chi^{2}$ test \\
\hline $3.0-3.4$ & 54 & 28 & 26 & 1.08 & $\mathrm{~ns}$ \\
\hline $3.5-3.9$ & 80 & 44 & 36 & 1.22 & $\mathrm{~ns}$ \\
\hline $4.0-4.4$ & 92 & 53 & 39 & 1.36 & $\mathrm{~ns}$ \\
\hline $4.5-4.9$ & 109 & 68 & 41 & 1.66 & $*$ \\
\hline $5.0-5.4$ & 158 & 103 & 55 & 1.87 & $*$ \\
\hline $5.5-5.9$ & 188 & 124 & 64 & 1.94 & $*$ \\
\hline $6.0-6.4$ & 183 & 123 & 61 & 2.02 & $*$ \\
\hline $6.5-6.9$ & 119 & 75 & 44 & 1.7 & $*$ \\
\hline $7.0-7.4$ & 54 & 35 & 19 & 1.84 & $*$ \\
\hline $7.5-7.9$ & 52 & 33 & 18 & 1.83 & $*$ \\
\hline $8.0-8.4$ & 98 & 64 & 34 & 1.88 & $*$ \\
\hline $8.5-8.9$ & 68 & 43 & 25 & 1.72 & $*$ \\
\hline
\end{tabular}

Significant $(\mathrm{P}<0.05)$ departs from 1:1 are indicated by *; ns - not significantly differ from 1:1 via chi square test

length weight relationship by sex.

\section{Seasonal occurrence of maturity stages}

The monthly evolution of maturity stages of males and females by percentage throughout the sampling period is given in Fig. 2. Mature females were found in all months. Immature ovaries were more prevalent during March-June, and the maximum percentage of mature ovaries was recorded during the months of October, January and February. No spent animals were recorded during the study.

More than $50 \%$ of the males are found to be mature throughout the year. Highest values were found from September-November and January-March. From the monthly evolution of maturity stages, could be concluded that the reproductive season of A. aegina occurred throughout the year. Greater reproductive activity occurred from July to February with a primary peak spawning activity during January-February followed by a secondary peak in October.

\section{Gonado Somatic index (GSI)}

Gonado Somatic index is used to monitor the breeding activity in a species. Analysis of gonadosomatic index for A. aegina showed annual changes especially in the case of females. Figure 3 shows the monthly changes in the gonadosomatic index for males and females respectively. Females showed a significant increase in the GSI from July to February, reaching a peak in October and another peak in January-February, coinciding with the major proportion of mature females. Gonado Somatic index showed a more or less consistent trend throughout the year. Two small peaks were produced in March and September coinciding with the major proportion of mature males. The range of GSI values obtained for different maturity stages of females were; Stage I: 0.023-2.98; Stage II: 3.71-5.89 and Stage III: 8.08119. 39. In males, the mean GSI values were $1.76 \pm 0.21$ (immature) and 2.95 \pm 0.69 (mature).

\section{Size at first maturity}

The smallest mature specimen collected in the sample was $4.8 \mathrm{~cm}$ DML in females and $3.6 \mathrm{~cm}$ DML in males. All the males were immature up to $3.4 \mathrm{~cm}$ mantle length. The percentage maturity gradually increased from $3.5-3.9 \mathrm{~cm}$ and $100 \%$ mature animals were found above $7.5-7.9 \mathrm{~cm}$ DML. The size at first maturity was estimated at $5.70 \mathrm{~cm}$ DML for males (Fig. 4).

All females, <4.4 cm DML were immature At 6.5$6.9 \mathrm{~cm}$ DML there was a sudden increase in maturity, and by $8.5 \mathrm{~cm}$ nearly $94 \%$ of females were mature The size at first maturity was estimated at $7.17 \mathrm{~cm}$ DML for females (Fig. 5). The weight at first maturity was estimated as $78.78 \mathrm{~g}$ for females and $40.78 \mathrm{~g}$ for males. The parameters of the logistics model $(\mathrm{a}, \mathrm{b})$ and the regression coefficients (r) obtained for male and female are shown in Table 3.

\section{Fecundity}

Fecundity varied from $2,962-8,820$ numbers in the individuals of mantle lengths ranged from $67-85 \mathrm{~mm}$. The mean fecundity of $A$. aegina estimated from these samples was 5,646 numbers.. Average relative fecundity was estimated 


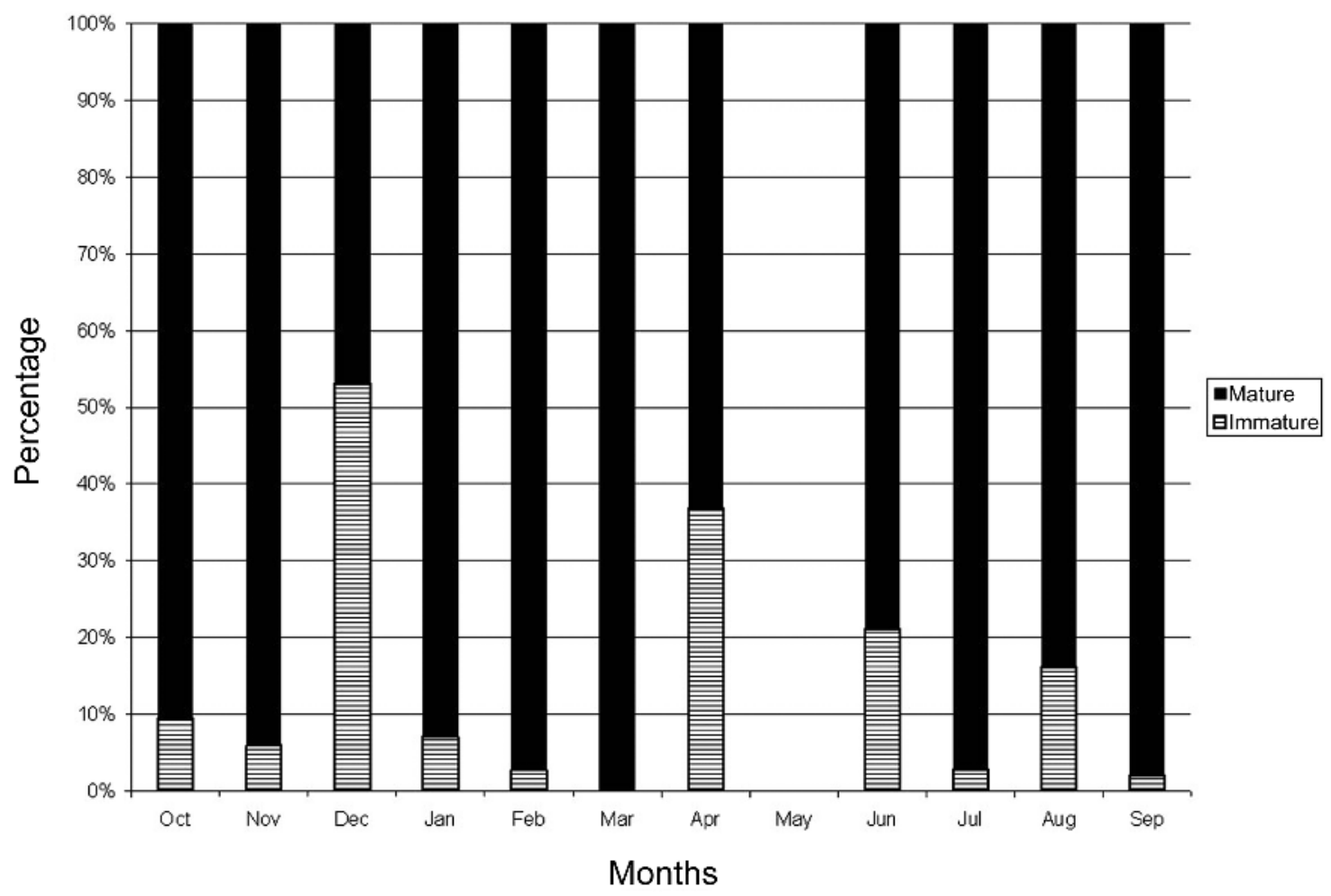

(A)

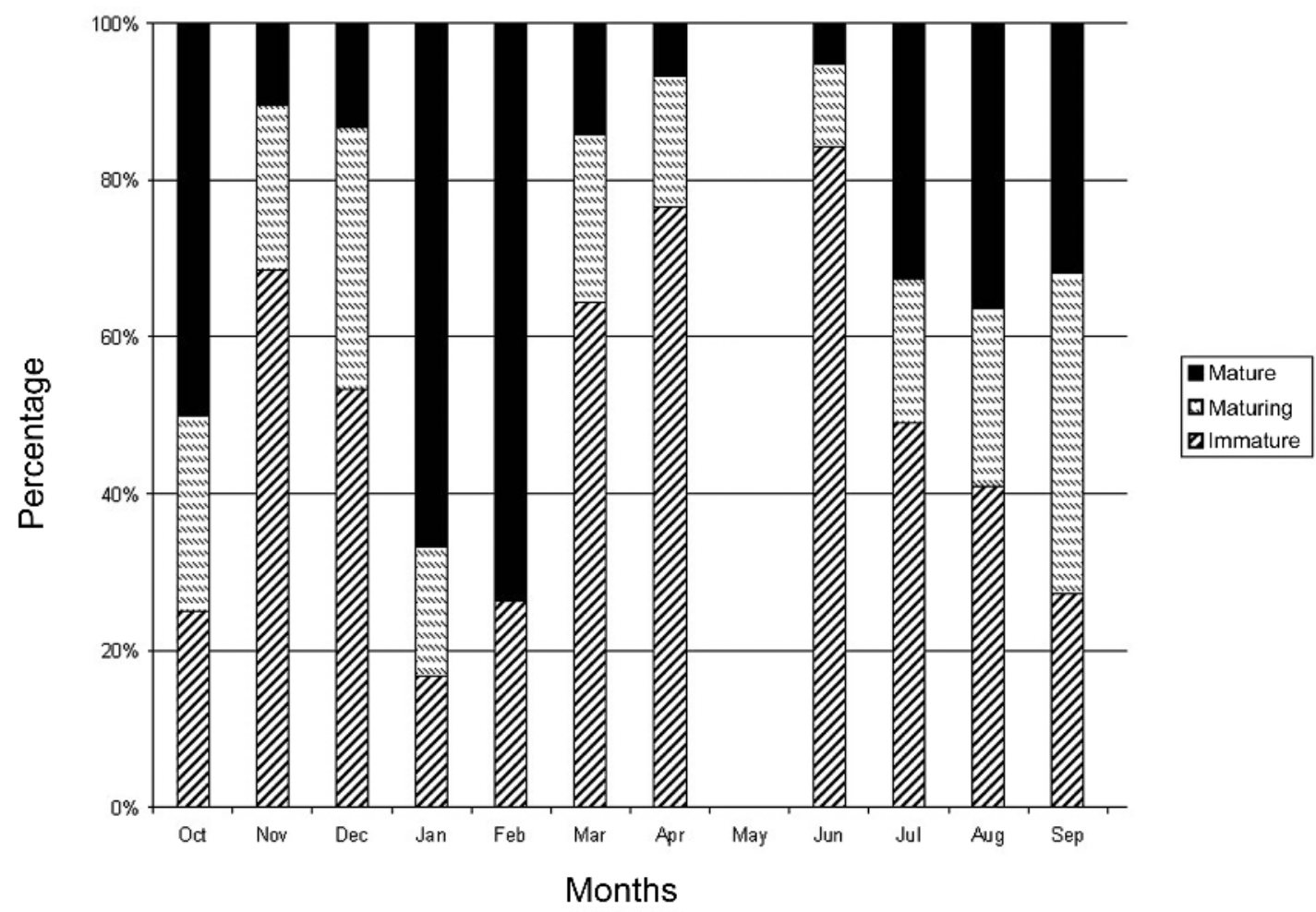

(B)

Fig. 2. Monthly percentage of different maturity stages of (A) male and (B) female Amphioctopus aegina during October 2001-September 2002 


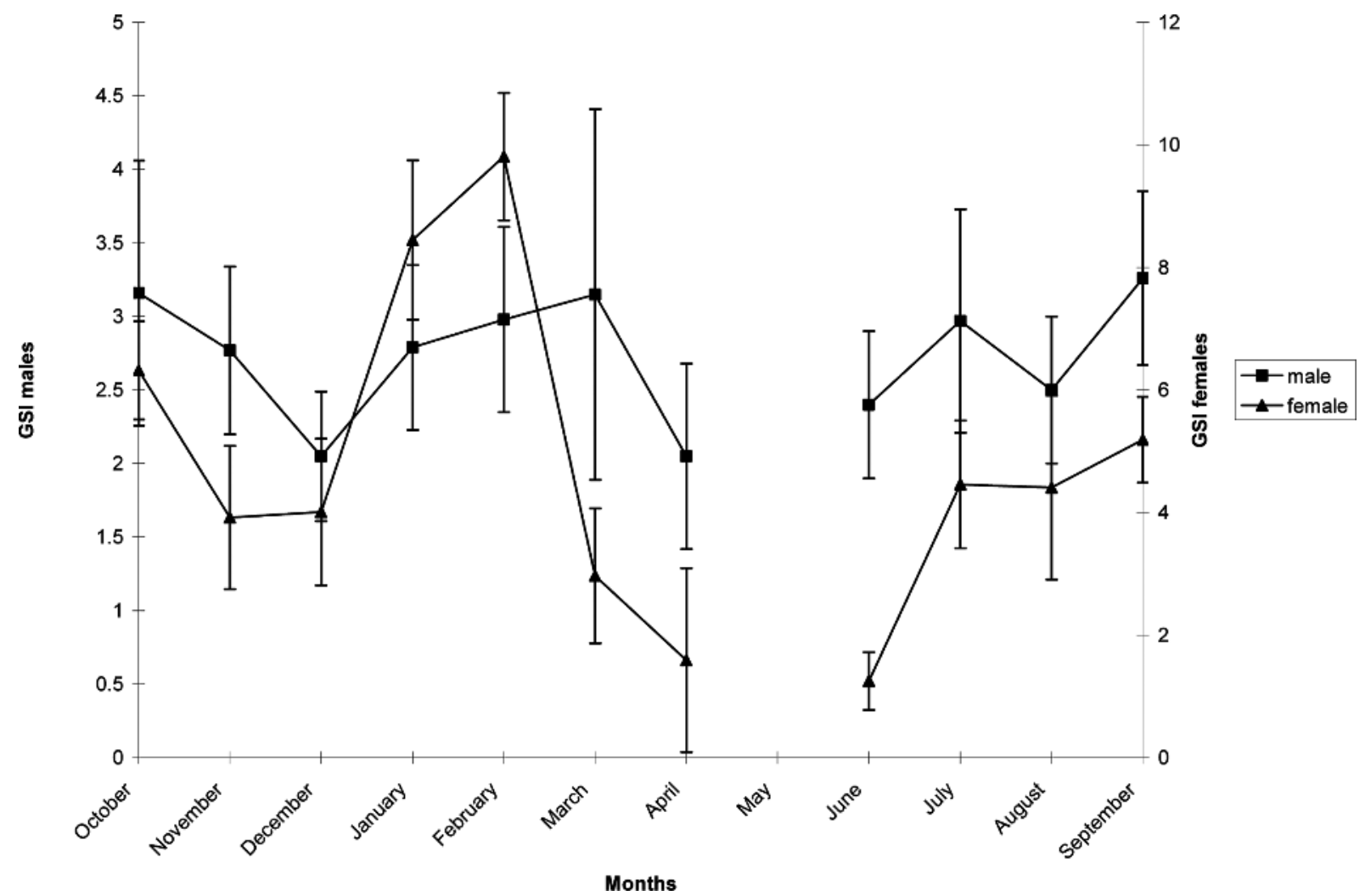

Fig. 3. Monthly variations of the gonadosomatic index $(\mathrm{GSI} \pm \mathrm{SD})$ in male and female Amphioctopus aegina. Vertical lines indicate the standard deviation $( \pm)$

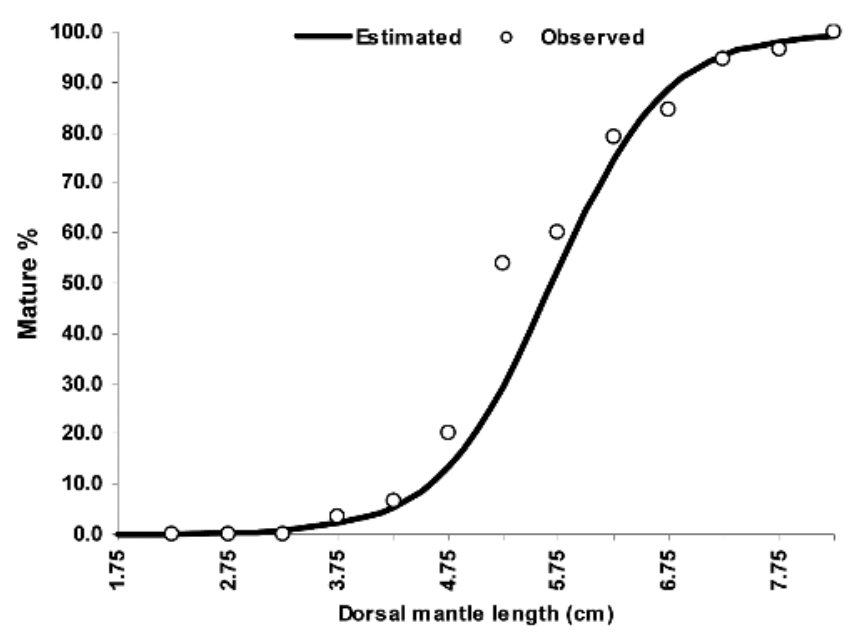

Fig. 4. Maturity ogive corresponding to dorsal mantle length for male Amphioctopus aegina

at $68 \pm 15.9$, numbers and the average number of oocytes per gram of ovary was estimated as $488 \pm 51.9$. The length of spermatophores in males ranged from $2.7-3.8 \mathrm{~cm}$. Figure 6 shows the relationship between size (DML), body weight (BW) and ovary weight $(\mathrm{OvW})$ with total fecundity.

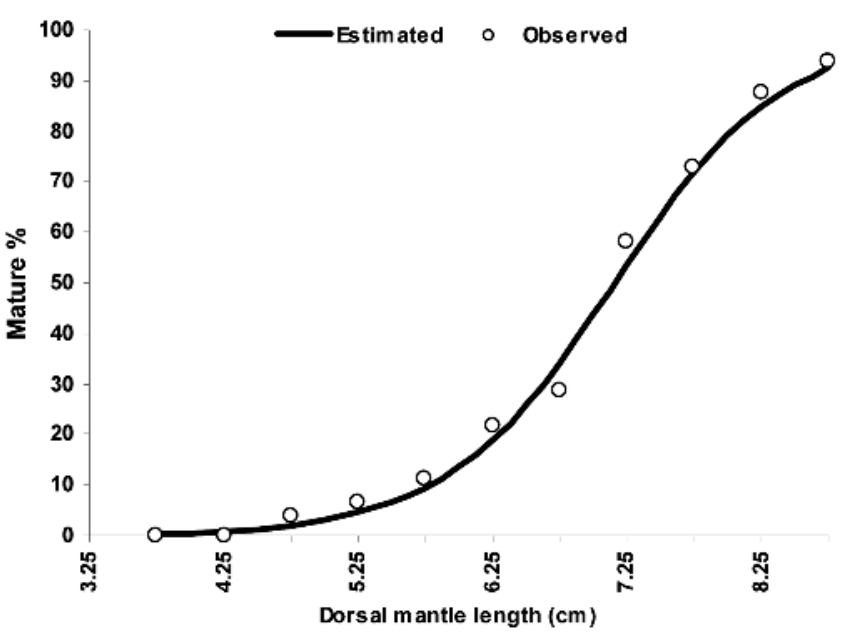

Fig. 5. Maturity ogive corresponding to dorsal mantle length for female Amphioctopus aegina

Table 4. Parameters of the logistic model (a, b) for weight and length and regression coefficient for male and female Amphioctopus aegina

\begin{tabular}{cccc}
\hline \hline & $\mathrm{a}$ & $\mathrm{b}$ & $\mathrm{r}^{2}$ \\
\hline Male DML & 11.13048 & -1.9536 & 0.9778 \\
Female DML & 11.44508 & -1.597 & 0.9731 \\
\hline
\end{tabular}



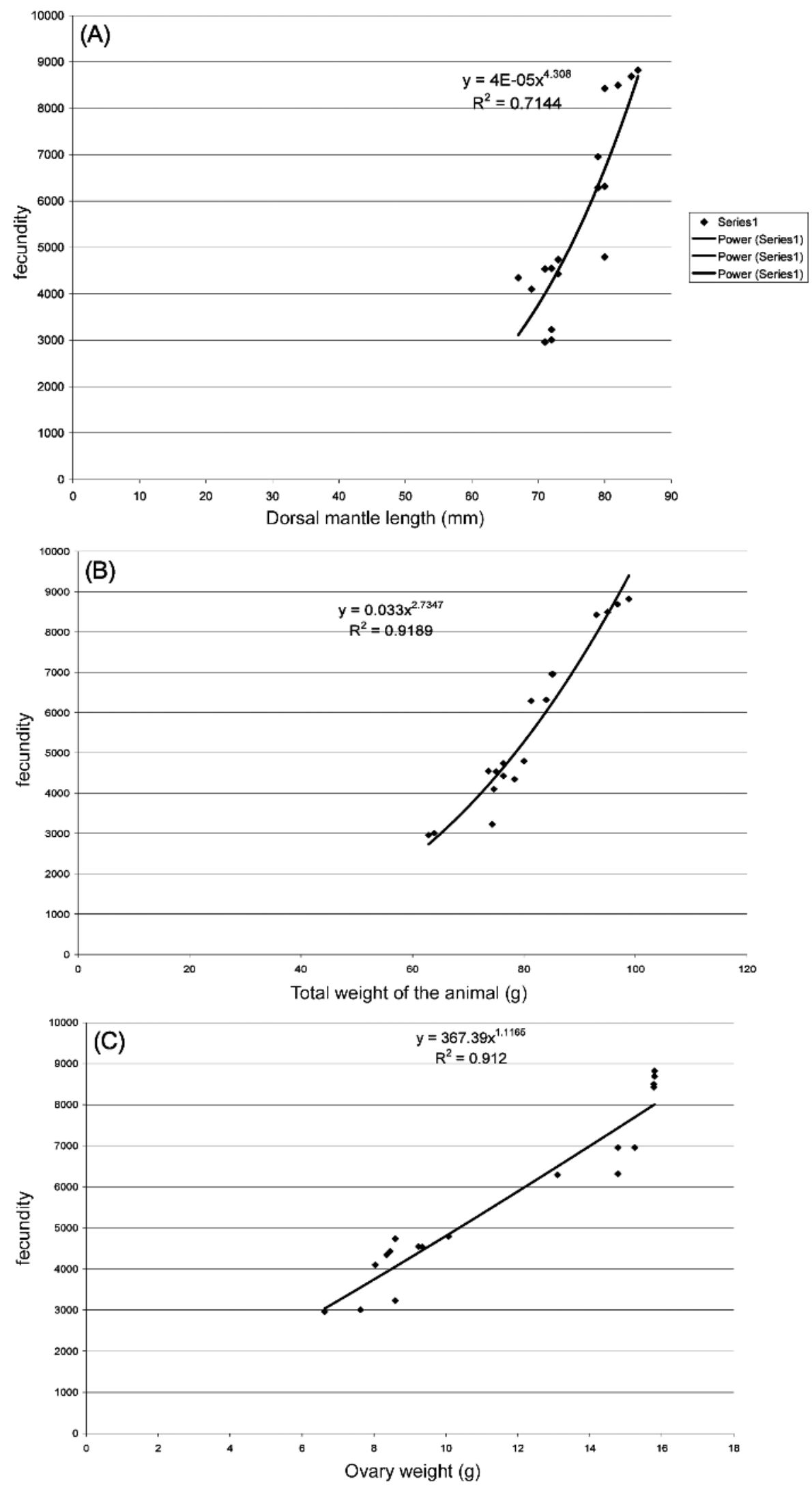

Fig. 6. Relationship between the total fecundity and (A) dorsal mantle length; (B) body weight and (C) ovary weight 


\section{Discussion}

This study reported higher numbers of males than females, and this is consistent with earlier work on field populations of Octopus sp. (Mangold Wirz 1963; Hatanaka 1979; Cortez et al. 1995; Hernanadez Garcia et al. 2002; Smith and Griffith 2002; Uriarte and Jara 2009). Males predominated in all months of sampling and the overall sex ratio showed a significant variation from the expected ratio of 1:1. The sex ratio observed in the catches was influenced by various factors like migrating behavior associated with sexual maturation, feeding behavior, post spawning mortality, differences in growth rates of sexes.Mangold Wirz 1963; Mangold 1983a). The different behavioral pattern of male and female $A$. aegina and the fishing method might also have influenced the sex ratio. Observations made on the specimens held in our laboratory, brooding females do not feed during the whole period and spend most of the time in its shelter ventilating and caring festoons which were held close to the body on the aboral side of the broad extensive interbrachial membrane (Ignatius and Srinivasan 2006). This wandering behavior of males make them more vulnerable to capture and the brooding females are less vulnerable to in bottom trawls as they were hiding in the shelters. This is reflected in the sex ratio during months coinciding with peak spawning.

The length weight relationship showed an allometric growth pattern and this too is consistent with earlier work regarding other Octopus species (Cortez et al. 1999; Smith and Griffiths 2002; Otero et al. 2007) Analysis of covariance showed insignificant variations between males and females. Various criteria such as size and colour of the gonad, ova measurements, Gonadosomatic Index were used by various workers in order to classify the maturity condition of the octopods and to determine the spawning season (Silva et al. 2002; Smith and Griffith 2002). Mangold (1987) suggested that beyond the rough distinction of immature, maturing and mature, no classification system could be applied to all cephalopods and to both sexes. In this study the female maturity stages were classified into four stages based on the maturity scale developed by Mangold (1983b) for $O$. vulgaris and found suitable for this species also. The brooding behavior of females and simultaneous terminal spawning behavior of this species were possible reasons for the non-availability of spent specimens of $A$. aegina. Difficulty in collection spent stages has also been reported by Arnold and Williams Arnold (1977), and; Mangold et al. (1993).

Amphioctopus aegina spawns throughout the year with a proportion of mature individuals present almost all months of the study, although this proportion increased at specific times of the year. There are two peaks in spawning activity each during months of October and January-February. A similar behavior has been reported for other species of octopods. As observed in the present study, various workers reported year round spawning activity for octopus species from various other areas (Wodinsky 1972; Van Heukelem 1973; Hatanaka 1979; Smale and Buchan 1981; Hartwick 1983; Whitaker et al. 1991; Hernandez Gracia et al. 2002; Silva et al. 2002; Smith and Griffith 2002; Uriarte and Jara 2009). Although previous information regarding the spawning season of this species in this area is lacking, several authors for various cephalopod species reported similar results of year round spawning with one or two spawning peaks (Rao 1969; Unnithan 1982; Silas et al. 1986) in this area. The peak spawning seasons of this species in Mandapam waters (Palk Bay) coincided with the onset and withdrawal of Northeast monsoon at this area. During this period, water temperature often falls below the normal average of $27^{\circ} \mathrm{C}$, and there are intermittent rains during this season. Among various factors that influence the sexual maturity of octopods, photoperiod and temperature play important roles (Mangold 1983; Forsythe and Hanlon 1988). All these environmental factors along with reduced day hours during this time may influence the gonad maturation and reproduction in this species.

The reproductive cycle of $A$. aegina was reflected by pronounced variations in gonad size. When assessing gonad activity, animals of different sizes are frequently sampled and it is generally assumed that gonad weight depends on animal size and stage of gonad development (De Vlaming et al. 1982). The gonad and the digestive gland increase in size with sexual maturation, and these contribute to why the maximum values of these indices occurred when there was maximum reproductive activity (Mangold 1983b).

The present study showed that the GSI values of females increased from July and reached a maximum value in October, and again in January and February, GSI values were also increased for males during this period. The high GSI values during these months indicated that the maximum gonad activity had taken place, indicating a probable spawning period of the species. Low GSI values 
during March to July showed a reduction in reproductive activity. In males, no definite seasonal change was observed in GSI values indicating that the males may breed throughout the year. A similar pattern of more or less constant GSI values throughout the year for males and one or two peak GSI values for females in an year, coinciding the spawning season females was observed in other octopods species (Hatanaka 1979; Silva et al. 2002; Smith and Griffith 2002) The size at first maturity for $A$. aegina available in this area was established as $5.70 \mathrm{~cm}$ DML for males and $7.17 \mathrm{~cm}$ DML for female. Several species of octopods show the same pattern in which males mature at smaller size than females (Hanlon 1983; Hartwick 1983; Mangold 1983, 1987; Cortez et al. 1995; Silva et al. 2002; Avila Poveda et al. 2009; Uriarte and Jara 2009)).

Knowledge of fecundity is extremely important from a viewpoint of successful fisheries management. Most of the authors defined fecundity as the number of ripening eggs in the ovary just before spawning (Norman and Sweeney 1997). In the present study, the average fecundity of $A$. aegina was estimated as 5,690. Chung (2000) estimated the fecundity of this species from Thailand as 2,000-10,000. Norman and Sweeney (1997) estimated the number of ovarian eggs in A. aegina as 1,000-10,000 depending upon the size of the animals. The fecundity values showed wide variations within the same species caught from different area. In $O$. vulgaris fecundity varied from 1,00,000$5,00,000$ from the samples collected from Thailand. It seems that environmental factors like food availability, its nutritive quality, and other environmental parameters play a role in determining the fecundity of the animal. Saville (1987) concluded that cephalopods have a wide range of fecundity, from $0.6 \mathrm{eggs} / \mathrm{g}$ of body weight to $200 \mathrm{eggs} / \mathrm{g}$ of body weight for octopus, and from 40-1,000 eggs/g for squids. This will be more reliable in making any comparison the values of fecundity per unit weight of the ovary of the animal. The average number of eggs $\mathrm{g}^{-1}$ of ovary was estimated as $488 \pm 51.9$ and number of eggs per gram of body weight as $68 \pm 15.9$ numbers. Similar values were reported made by Saville (1987) in various octopus species. The present study provided some important information on the reproductive traits of sandbird octopus, Amphioctopus aegina (Gray, 1849) from Mandapam coastal waters (Palk Bay), southeast coast of India which will be useful in developing strategies management and conservation of this resource.

\section{Acknowledgments}

We thank the authorities of Annamalai University, Prof. T. Balasubramanian, Director and Dean, Centre of Advanced Study in Marine Biology, Faculty of Marine Sciences, Parangipettai, and Central Marine Fisheries Research Institute (CMFRI), Cochin India for support and help.

\section{References}

Alvarez Perez JA, Haimovici M (1991) Sexual maturation and reproductive cycle of Eledone massyae, Voss 1964 (Cephalopoda: Octopodidae) in southern Brazil. Bull Mar Sci 49:270-279

Alves J, Haimovici M (2011) Reproductive biology of Octopus tehuelchus d'Orbigny, 1834 (Cephalopoda: Octopodidae) in southern Brazil. The Nautilus 125(3):150-158

Arnold JM, Williams Arnold LD (1977) Cephalopoda: Decapoda. In: A.C. Giese and J.S. Pearse (eds) Reproduction of marine invertebrates. Vol. 4. Academic Press, New York, pp 243-290

Avila Poveda OH, Colin Flores RF, Rosas C (2009) Gonad Development during the Early Life of Octopus maya (Mollusca: Cephalopoda). Biol Bull 216:94-102

Barratt IM, Johnson MP, Allcock AL (2007) Fecundity and reproductive strategies in deep-sea incirrate octopuses (Cephalopoda: Octopoda). Mar Biol 150:387-398

Bensam P (1999) Development of marine fisheries science in India. Daya Publishing House, Delhi, pp 379

Buckley SKL (1976) Oogenesis and its hormonal control in Octopus vulgaris. Ph.D. thesis, University of Cambridge, London

Chung WS (2000) Aspects of the life history of Amphioctopus aegina (Gray, 1849) from Taiwan. B.S. thesis, Department of Zoology, National Chung-Hsing University, Taichung, Taiwan

CMFRI (2009) Annual Report, 2009. Central Marine Fisheries Research Institute, $135 \mathrm{p}$

Cortez T, Castro BG, Guerra A (1995) Reproduction and condition of female Octopus mimus (Mollusca: Cephalopoda). Mar Biol 123:505-510

Cortez T, Gonzalez AF, Guerra A (1999) Growth of cultured Octopus mimus (Cephalopoda: Octopodidae). Fish Res 40:8189

DeVlaming VL, Grossman G, Chapman F (1982) On the use of gonadosomatic index. Comp Biochem Physiol A 73(1):31- 39

Forsythe JW, Hanlon RT (1988) Effect of temperature on laboratory growth, reproduction and life span of Octopus bimaculoides. Mar Biol 98:369-379

Gabra HR, Hanlonb RT, Hanafya MH, El-Etreby SG (1998) Maturation, fecundity and seasonality of reproduction of two 
commercially valuable cuttlefish, Sepia pharaonis and $S$. dollfusi, in the Suez Canal. Fish Res 36:99-115

Goncalves JM (1991) Biology and exploitation of Octopus vulgaris Cuvier 1797 (Mollusca: Cephalopoda). ICES, Copenhagen-Denmark, $13 \mathrm{p}$

Guerra A (1975) Determination de las diferentes fases del desarrollo sexual de Octopus vulgaris Lam. Mediante un indice de madurez. Inv Pesq 39:397-416

Hanlon RT (1983) Octopus joubini. In: Boyle PR (ed) Cephalopod Life Cycles. Vol. 1: Academic Press, London, pp 293-310

Hartwick B (1983) Octopus dofleini. In: Boyle PR (ed) Cephalopod life cycles. Vol. I: Academic Press, London, pp 277-291

Hatanaka H (1979) Studies on the fisheries biology of common octopus off the northwest coast of Africa. Bull Far Seas Fish Res Lab 17:13-124

Hernandez Gracia V, Hernandez-Lopez JL, Castro Hdez JJ (2002) On the reproduction of Octopus vulgaris off the coast of the Canary Islands. Fish Res 57:197-203

Ignatius B (2005) Fishery and biology of the selected octopus species Octopus aegina Gray, 1849 from Mandapam waters (Palk Bay), southeast coast of India. Ph.D. thesis, Annamalai University, India, $188 \mathrm{p}$

Ignatius B, Srinivasan M (2006) Embryonic development of Octopus aegina (Gray, 1849). Curr Sci 91(8):1089-1092

López-Uriarte E, Rios-Jara E (2009) Reproductive Biology of Octopus Hubbsorum (Mollusca: Cephalopoda) Along the Central Mexican Pacific Coast. Bulletin of Marine Science 84(1):109-121

Mangold K (1983) Octopus vulgaris In: Boyle PR (ed) Cephalopod Life Cycles. Vol. 1: Academic Press, London, pp 335-364

Mangold K (1983a) Food, feeding and growth in cephalopods. Mem Nat Mus Victoria Melbourne 44:81-93

Mangold K (1983b) Octopus vulgaris In: Boyle PR (ed) Cephalopod Life Cycle. Vol. I. Species account. Academic Press, London, pp 335-364

Mangold K (1987) Reproduction. In: Boyle PR (ed) Cephalopod Life Cycles. Vol. 2: Academic Press, London, pp 157-200

Mangold KM, Young RE, Nixon M (1993) Growth versus maturation in cephalopods. In: Okutani T, O'Dor RK, Kubodera $\mathrm{T}$ (eds) Recent advances in cephalopod fisheries biology. Tokai University Press, Tokyo, pp 697-703

Mangold Wirz K (1963) Biologie des cephalopods benthiques et nectonique del la Mer catalane. Vie Milieu 13:1-285

Norman MD, Sweeney MJ (1997) The shallow water octopuses (Cepahlopoda-Octopodidae) of the Philippines. Invert Taxo 11:89-140

Otero J, Gonzalez AF, Sieiro MP, Guerra A (2007) Reproductive cycle and energy allocation of Octopus vulgaris in Galician waters, NE Atlantic. Fish Res 85:122-129

Rao KV (1969) Biology and fishery of Palk bay squid Sepioteuthis arctipinnis. Gould Ind J Fish 1:37-66
Rocha F, Guerra A, Gonzalez AF (2001) A review of reproductive strategies in cephalopods. Biol Rev 76(3):291-304

Sanchez P, Obarti R (1993) The biology and fishery of Octopus vulgaris caught with clay pots on the Spanish Mediterranean coast. In: Okutani T, O’Dor, RK, Kubodera T (eds) Recent Advances in Cephalopod Fisheries Biology. Tokai Univeristy Press, Tokyo, Japan, pp 477-487

Saville A (1987) Comparison between cephalopods and fish of those aspects of the biology related to stock management. In: Boyle PR (ed) Cephalopod Life Cycles: Vol. II. Comparative Reviews. Academic Press Inc. London, pp 277-290

Semmens JM, Pecl GT, Villanueva R, Jouffre D, Sobrino I, Wood JB, Rigby PR (2004) Understanding octopus growth: Patterns, variability and physiology. Mar Freshwat Res 55:367-377

Silas EG, Sarvesan R, Meiyappan MM, Prabhakaran Nair K, Satyanarayana Rao K, Kuber Vidyasagar, Appanna Sastri Y, Srinivasan PV, Narayana Rao B (1986) Cephalopod fisheries at selected centres in India. Bull Centr Mar Fish Res Inst 37:116-128

Silva L, Sobrino I, Ramos F (2002) Reproductive biology of the common octopus Octopus vulgaris Cuvier, 1797 (Cephalopoda: Octopodidae) in the Gulf of Cadiz (SW Spain). Bull Mar Sci 71(2):837-850

Smale MJ, Buchan PR (1981) Biology of Octopus vulgaris off the east coast of South Africa. Mar Biol 65(1):1-12

Smith CD, Griffiths CL (2002) Aspects of the population biology of Octopus vulgaris in False Bay, South Africa. S Afr J Mar Sci 24:185-192

Smith CD, Groeneveld JC, Maharaj G (2006) The life history of the giant octopus Octopus magnificus in South African waters. Afr J Mar Sci 3-4:561-568

Snedecor GW, Cochran WG (1967) Statistical methods. 6th Edition. Lowa University Press, Amsterdam, 593 p

Stephen C, Leporati, Gretta T, Pecl, Jayson M, Semmens (2008) Reproductive status of Octopus pallidus, and its relationship to age and size. Mar Biol 155:375-385

Unnithan KA (1982) Observations on the biology of cuttlefish sepiella inermis at Mandapam. Ind J Fish 29(1\&2):101-111

Uriarte L, Ernesto, Jara R, Eduardo (2009) Reproductive Biology of Octopus Hubbsorum (Mollusca: Cephalopoda) Along the Central Mexican Pacific Coast. Bull Mar Sci 84(1):109-121

Van Heukelem WF (1973) Growth and life span of Octopus cyanea (Mollusca: Cephalopoda). J Zool Lond 169:299-315

Wells MJ, Wells J (1977) Cephalopoda: Octopoda. In: Giese AC Pearse JS (eds) Reproduction of marine invertebrates. Vol. 4: Academic Press, New York, pp 291-336

Whitaker JD, De Lancey LB, Jenkins JE (1991) Aspects of biology and fishery potential for Octopus vulgaris off the coast of south California. Bull Mar Sci 49(1\&2):482-493

Wodinsky J (1972) Breeding season of Octopus vulgaris. Mar Biol 16:59-63 